Notes and Comments

\title{
First record of Epibiont ciliates (Ciliophora: Peritrichia) associated with Dero digitata Müller, 1773 (Oligochaeta: Naididae) in Brazil
}

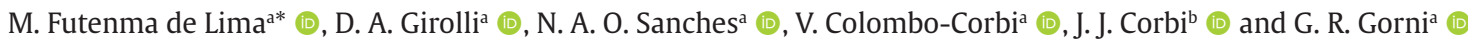 \\ aniversidade de Araraquara - UNIARA, Programa de Pós-graduação em Desenvolvimento Territorial e Meio Ambiente, Araraquara, SP, Brasil \\ 'Universidade de São Paulo - USP, Departamento de Hidráulica e Saneamento - SHS, Laboratório de Ecologia de Ambientes Aquáticos - LEEA, \\ São Carlos, SP, Brasil
}

Epibiosis is the facultative association between two organisms: the epibiont (colonizes the surface of living substrates) and the basibiont (the host). The association effects can have both positive and negative aspects (Wahl, 1989; Fernandez-Leborans and Tato-Porto, 2000; Dias et al., 2007). In aquatic environments, one of the positive effects of epibiosis is the transport of epibionts for places with greater food availability and dissolved oxygen (RegaliSeleghim and Godinho, 2004). However, for hosts, this relationship may cause negative effects, as recorded in the work of Henebry and Ridgeway (1979), whose presence of protozoa impaired the host's swimming efficiency. Also, Laird (1959) reported that heavy of epibiont on mosquito larvae limited their feeding activities, which came close to establishing a parasitism relationship, which can decrease the host's ability to survive.

Epibiont ciliates play an important ecological role in freshwater ecosystems such as control of bacterial density (Sanders et al., 1989; Berninger et al., 1991; Zingel et al., 2007) and alteration of the morphological and taxonomic composition of bacterial communities by predation (Jurgens and Gude, 1994; Jurgens et al., 1997). However, most research related to these organisms is of morphological and taxonomic aspects (Baldock, 1986). Many epibionts use animals and plants as a substrate during their lives (Dias et al., 2007). For example, the organisms from the genus Rhabdostyla Kent, 1880 (Peritrichia, Epistylidae) live associated with freshwater invertebrates, such as rotifers, crustaceans (Cladocerans, Copepods), insects of the orders Ephemeroptera and Diptera (Chironomidae) and annelids (Oligochaeta and Polychaeta) (Fernandez-Leborans and Tato-Porto, 2000; Regali-Seleghim and Godinho, 2004; Dias et al., 2007). Other species of Epibiont ciliates were also recorded in Plecoptera insects (Avelino-Capistrano, 2010) and in the larval stage of Odonata and Ephemeroptera (Corbi et al. 2017; Abrahão et al., 2017).

The Oligochaeta Class is one of the most abundant groups in freshwater systems. With wide distribution, these worms playing a fundamental role in the decomposition and cycling of organic matter (Loteste and Marchese, 1994; Martins et al., 2008; Esteves et al., 2011). Oligochaeta inhabit several microhabitats from aquatic environments, which can be registered in sediments and water column (Rodriguez and Reynoldson, 2011), in association with other organisms, such as aquatic macrophytes (Gorni and Alves, 2008), bryophytes (Gorni and Alves, 2007), sponges (Alves and Gorni, 2007), insect larvae (Corbi et al., 2004) and amphibians (Oda et al., 2015). In addition, these organisms are recognized as biological indicators of the water quality in aquatic environments (Prygiel et al., 2000).

In general, research involving the association of Epibiont ciliates with oligochaetes refers only to the occurrence and description of species. However, there are studies that have registered this association and its ecological relationships with aquatic oligochaetes of the families: Tubificidae, Lumbriculidae and Naididae (Kahl, 1935; Precht, 1935; Nenninger, 1948; Righi, 1973; Smith, 1986; Foissner et al., 1992; Dias et al., 2009).

We report the first record of Epibiont ciliates (Ciliophora: Peritrichia) associated with an aquatic Oligochaeta, Dero digitata Müller, 1773 in Brazil. Previously, there is only one record of Rhabdostyla (Ciliophora: Peritrichia) on D. digitata in Ozaukee County, Wisconsin - United States (Smith, 1986). The organisms were collected in September 2015 , in the Monjolinho reservoir region ( $47^{\circ} 53^{\prime} \mathrm{W}$ and $22^{\circ} 01$ 'S), using aquatic " $D$ " net, during a survey of benthic macroinvertebrates. This reservoir is located on the campus of the Federal University of São Carlos (São Carlos, São Paulo, Brazil). The Oligochaeta species was identified using the taxonomic criteria adopted by Brinkhurst and Jamieson (1971) and Brinkhurst and Marchese (1989). The epibiont ciliates (Ciliophora: Peritrichia) were found associated with the branchial fossa region of the oligochaetes (Figure 1).

Some species of aquatic oligochaetes have respiratory gills and appendages in the posterior region of the body and these structures increase the absorption of oxygen (Raposeiro et al., 2009). Among these species, D. digitata is considered tolerant to organic pollution - a characteristic linked to the ability to tolerate environments with reduced oxygen availability (Brinkhurst and Marchese, 1989; Takeda, 1999). According to some authors, the oxygen supply is an important factor for the location of ciliates in specific

*e-mail: futenma19@gmail.com

Received: April 1, 2020 - Accepted: September 11, 2020 

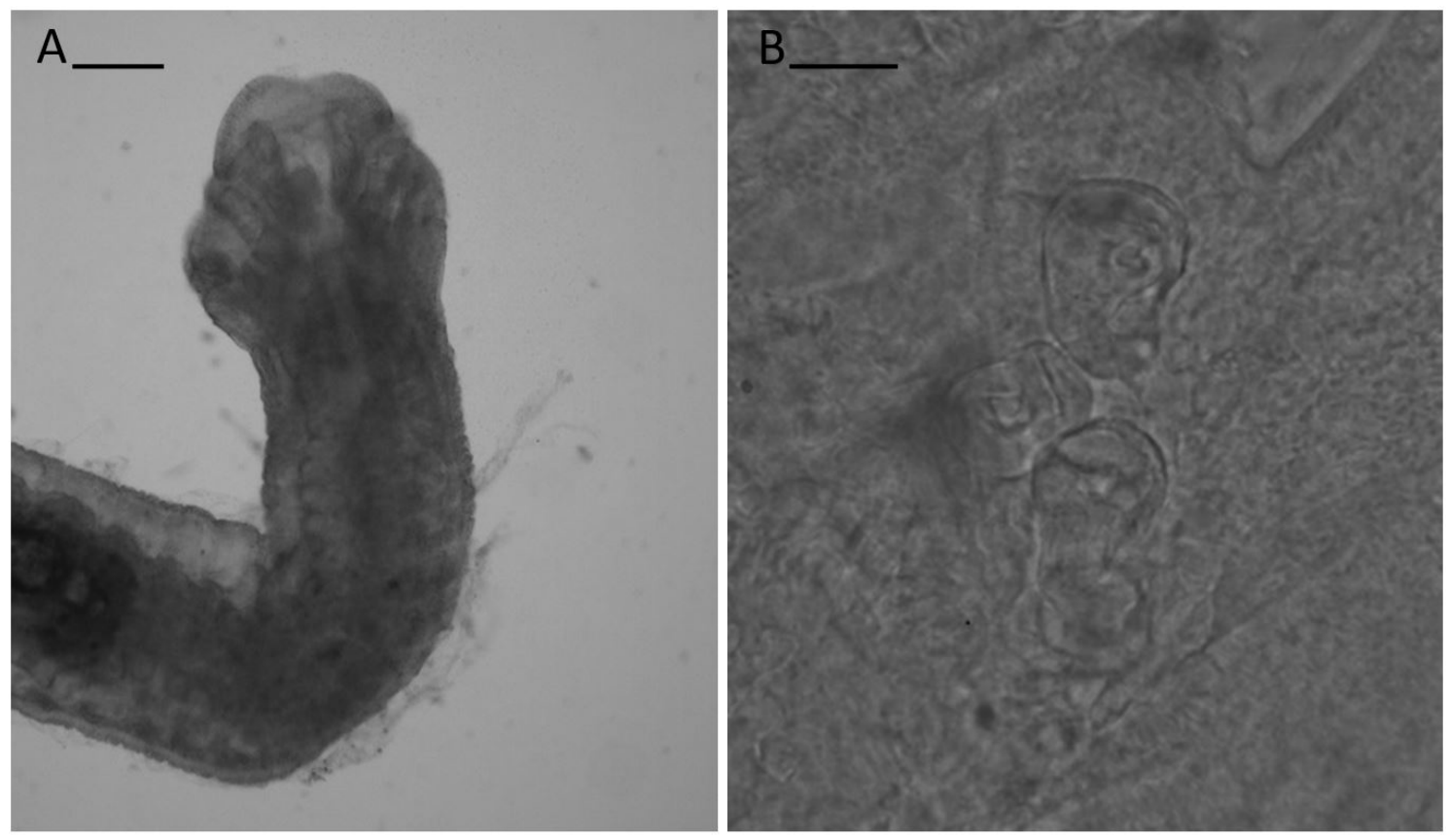

Figure 1. Dero digitata. (A) brachial fossa; (B) epibiont ciliates associated with the posterior region. Scale bars: (A) $100 \mu \mathrm{m}$ and (B) $10 \mu \mathrm{m}$.

regions in the body of the hosts (Smith, 1986; Dias et al., 2007). This preference reflects the ecological needs of the epibiont, determined by the environmental conditions, as well as the biology and behavior of the hosts (Fenchel, 1965; Fernandez-Leborans et al., 1997). Smith (1986) attributed the presence of the largest number of Epibiont ciliates in the posterior region of Dero nivea Aiyer, 1930 to the ventilation generated by the gills of these organisms. Similarly, Dias et al. (2009) recorded in a polluted stream in the neotropical region highest concentration of ciliate in the posterior region of Limnodrilus hoffmeisteri Claparède, 1862.

The presence of ciliates associated with the gill's region of $D$. digitata does not seem to offer negative effects. However, adherence to the prostomial region would probably harm your diet. Some authors report that ciliates feed mainly on bacteria, and their location in the body of the hosts is indifferent (Henebry and Ridgeway, 1979; Zingel et al., 2007). Therefore, considering the information on the biology and ecology of Epibiont ciliates, our observations may be related to the preference of ciliate adhesion to a basibiont that provides ideal conditions for their survival.

In this study, we obtained the first record of associated Epibiont ciliates in one individual of the species $D$. digitata. Thus, we consider it important to carry out further studies in order to provide details on the ecological interactions between Epibiont ciliates and aquatic Oligochaeta.

\section{Acknowledgements}

We would like to thank financial support: FAPESP, process number 2018/12069-9 and Coordenação de
Aperfeiçoamento de Pessoal de Nível Superior - Brasil (CAPES).

\section{References}

ABRAHÃO, D.P., MELLO, J.L., GORNI, G.R. and CORBI, J.J., 2017. First report of Epibiont ciliates (Ciliophora: Peritrichia) living on larvae of Leptophlebiidae (Ephemeroptera) from Brazil. Brazilian Archives of Biology and Technology, vol. 60, e17160294. http:// dx.doi.org/10.1590/1678-4324-2017160294.

ALVES, R.G. and GORNI, G.R., 2007. Naididae species (Oligochaeta) associated with submersed aquatic macrophytes in two reservoirs (São Paulo, Brazil). Acta Limnologica Brasiliensia, vol. 19, no. 4, pp. 407-413.

AVELINO-CAPISTRANO, F.S., 2010. Plecoptera (Insecta) immatures in streams of Biological Station of Santa Lúcia, Espírito Santo, Brazil: spatial and sazonal distribution, and substrate preference. Seropédica: Instituto de Biologia, Universidade Federal Rural do Rio de Janeiro. Master Science in Animal Biology.

BALDOCK, B.M., 1986. Peritrich ciliates on larvae of Brachycentrus subnubilus (Tricoptera): importance in relation to the total protozoan population in streams. Hydrobiologia, vol. 132, no. 2, pp. 125-131. http://dx.doi.org/10.1007/BF00006775.

BERNINGER, U.G., FINLAY, B.J. and KUUPPO-LEINIKKI, P., 1991. Protozoan control of bacterial abundances in freshwater. Limnology and Oceanography, vol. 36, no. 1, pp. 139-147. http:// dx.doi.org/10.4319/lo.1991.36.1.0139.

BRINKHURST, R.O. and JAMIESON, B.G.M., 1971. Aquatic Oligochaeta of the world. Toronto: University of Toronto Press, $860 \mathrm{p}$.

BRINKHURST, R.O. and MARCHESE, M.R., 1989. Guia para la identificación de oligoquetos acuáticos continentales de Sud y Centroamerica. Santa Fé: Asociación de Ciências Naturales del Litoral, 207 p. 
CORBI, J.J., ABRAHÃO, D.P., MELLO, J.L.S. and GORNI, G.R., 2017. Record of Epibiont ciliates (Ciliophora: Peritrichia) living on larvae of Odonata from Brazil. Brazilian Journal of Biology = Revista Brasileira de Biologia, vol. 77, no. 2, pp. 417-419. http:// dx.doi.org/10.1590/1519-6984.19115. PMid:27579979.

CORBI, J.J., JANCSO, M.A., STRIXINO, S.T. and FRAGOSO, E.N., 2004 Occurence of Oligochaeta living on larvae of Odonata from Ipeúna (São Paulo State, Brazil). Biota Neotropica, vol. 4, no. 2 , pp. 1-3. http://dx.doi.org/10.1590/S1676-06032004000200017.

DIAS, R.J.P., CABRAL, A.F., MARTINS, R.T., STEPHAN, N.N.C., SILVANETO, I.D., ALVES, R.G. and D'AGOSTO, M., 2009. Occurrence of peritrich ciliates on the limnic oligochaete Limnodrilus hoffmeisteri (Oligochaeta, Tubificidae) in the neotropics. Journal of Natural History, vol. 43, no. 1-2, pp. 1-15. http://dx.doi. org/10.1080/00222930802478644.

DIAS, R.J.P., CABRAL, A.F., STEPHAN, N.N.C., MARTINS, R.T., SILVANETO, I.D., ALVES, R.G. and D'AGOSTO, M., 2007. Record of Rhabdostyla chironomi Kahl, 1933 (Ciliophora, Peritrichia) Epibiont on Chironomidae larvae (Diptera, Chironomidae) in a lotic system in Brazil. Brazilian Journal of Biology = Revista Brasileira de Biologia, vol. 67, no. 4, pp. 783-785. http://dx.doi. org/10.1590/S1519-69842007000400030. PMid:18278337.

ESTEVES, F.A., LEAL, J.J.F. and CALLISTO, M., 2011. Fundamentos de limnologia. 3. ed. Rio de Janeiro: Interciência, 790 p.

FENCHEL, T., 1965. On the ciliate fauna associated with the marine amphipod Gammarus J.G. Fabricius. Ophelia, vol. 2, no. 2, pp. 281-303. http://dx.doi.org/10.1080/00785326.1965.10409605.

FERNANDEZ-LEBORANS, G. and TATO-PORTO, M.L., 2000. A Review of the species of protozoan epibionts on crustaceans. I. Peritrich ciliates. Crustaceana, vol. 73, no. 6, pp. 643-683. http://dx.doi. org/10.1163/156854000504705.

FERNANDEZ-LEBORANS, G., CORDOBA, M.J.H. and DEL ARCO, P.G., 1997. Distribution of ciliate epibionts on the portunid crab Liocarcinus depurator (Decapoda, Brachyura). Invertebrate Biology, vol. 116, no. 3, pp. 171-177. http://dx.doi.org/10.2307/3226894.

FOISSNER, W., BERGER, H. and KOHMANN, F., 1992. Taxonomische und ökologische Revision der Ciliaten des Saprobiensystems - Band II: Peritricha, Heterotricha, Odontostomatida. Informationsberichte des Bayer. Landesamtes für Wasserwirtschaft, vol. 92, no. 5, pp. 1-502.

GORNI, G.R. and ALVES, R.G., 2007. Naididae (Annelida, Oligochaeta) associated with briophytes in Brotas, State of São Paulo, Brazil. Revista Brasileira de Zoologia, vol. 24, no. 2, pp. 518-519. http:// dx.doi.org/10.1590/S0101-81752007000200036.

GORNI, G.R. and ALVES, R.G., 2008. Oligochaeta (Annelida: Clitellata) em córregos de baixa ordem do Parque Estadual de Campos do Jordão (São Paulo - Brasil). Biota Neotropica, vol. 8, no. 4, pp. 161-165. http://dx.doi.org/10.1590/S1676-06032008000400016.

HENEBRY, M.S. and RIDGEWAY, B.T., 1979. Epizoic ciliated protozoa of planktonic Copepods and Cladocerans and their possible use as indicators of organic pollution. Transactions of the American Microscopical Society, vol. 98, no. 4, pp. 495-508. http://dx.doi. org/10.2307/3225899.

JÜRGENS, K. and GÜDE, H., 1994. The potential importance of grazing-resistant bacteria in planktonic systems. Marine Ecology Progress Series, vol. 112, pp. 169-188. http://dx.doi. org/10.3354/meps112169.

JÜRGENS, K., ARNDT, H. and ZIMMERMANN, H., 1997. Impact of metazoan and protozoan grazers on bacterial biomass distribution in microcosm experiments. Aquatic Microbial Ecology, vol. 12, no. 2, pp. 131-138. http://dx.doi.org/10.3354/ ame012131.
KAHL, A., 1935. Urtiere oder Protozoa I: Wimpertiere oder Ciliata (Infusoria) 4. Peritricha und Chonotricha. In: F. DAHL, ed. Die Tierwelt Deutschlands. Jena, Germany: G. Fischer, part 30, pp. 651-805.

LAIRD, M., 1959. Parasites of Singapore mosquitoes with particular reference to the significance of larval epibionts as an index of habitat pollution. Ecology, vol. 40, no. 2, pp. 206-221. http:// dx.doi.org/10.2307/1930031.

LOTESTE, A. and MARCHESE, M., 1994. Ammonium excretion by Paranadrilus descolei Gavrilov, 1955 and Limnodrilus hoffmeisteri Clapare'de, 1862 (Oligochaeta: Tubificidae) and their role in nitrogen delivery from sediment. Polskie Archiwum Hydrobiologii, vol. 41, pp. 189-194.

MARTINS, R.T., STEPHAN, N.N.C. and ALVES, R.G., 2008. Tubificidae (Annelida: Oligochaeta) as an indicator of water quality in an urban stream in southeast Brazil. Acta Limnologica Brasiliensia, vol. 20, no. 3, pp. 221-226.

NENNINGER, U., 1948. Die Peritrichen der Umgebung von Erlangen mit besonderer Berucksichtigung ihrer Wirtsspezifitat. Zoologische Jahrbücher Jena Systematik, vol. 77, pp. 169-266.

ODA, F.H., PETSCH, D.K., RAGONHA, F.H., BATISTA, V.G., TAKEDA, A.M. and TAKEMOTO, R.M., 2015. Dero (Allodero) lutzi Michaelsen, 1926 (Oligochaeta: Naididae) associated with Scinax fuscovarius (Lutz, 1925) (Anura: Hylidae) from Semi-deciduous Atlantic Rain Forest, Southern Brazil. Brazilian Journal of Biology = Revista Brasileira de Biologia, vol. 75, no. 1, pp. 86-90. http://dx.doi. org/10.1590/1519-6984.07613. PMid:25945624.

PRECHT, H., 1935. Epizoen der Kieler Bucht. Nova Acta Leopoldina, vol. 3, pp. 405-475.

PRYGIEL, S.J., ROSSO-DARMET, A., LAFONT, M., LESNIAK, C., DURBEC, A. and OUDDANE, B., 2000. Use of Oligochaete communities for assessment of ecotoxicological risk in fine sediment of rivers and canals of the Artois-Picardie water basin (France). Hydrobiologia, vol. 410, pp. 25-37. http://dx.doi. org/10.1023/A:1003799224961.

RAPOSEIRO, P.M., RAMOS, J.C. and COSTA, A.C., 2009. First record of Branchiura sowerbyi Beddard, 1982 (Oligochaeta: Tubificidae) in Azores. Aquatic Invasions, vol. 4, no. 1, pp. 487-490. http:// dx.doi.org/10.3391/ai.2009.4.3.8.

REGALI-SELEGHIM, M.G. and GODINHO, M.J.L., 2004. Peritrich epibiont protozoans in the zooplankton of a subtropical shallow aquatic ecosystem (Monjolinho Reservoir, São Carlos, Brazil). Journal of Plankton Research, vol. 26, no. 5, pp. 501-508. http:// dx.doi.org/10.1093/plankt/fbh055.

RIGHI, G., 1973. On Pristina minuta (Oligochaeta, Naididae) from Brazilian soil and its epizoic Rhabdostyla pristinis sp. n. (Ciliata, Epistylidae). Zoologischer Anzeiger, vol. 191, pp. 295-299.

RODRIGUEZ, P. and REYNOLDSON T.B., 2011. The pollution biology of aquatic oligochaetes. Dordrecht: Springer Science and Business Media, 265 p. http://dx.doi.org/10.1007/97894-007-1718-3.

SANDERS, R.W., PORTER, K.G., BENNETT, S.J. and DEBIASE, A.E., 1989. Seasonal patterns of bacterivory by flagellates, ciliates, rotifers, and cladocerans in freshwater planktonic community. Limnology and Oceanography, vol. 34, no. 4, pp. 673-687. http:// dx.doi.org/10.4319/lo.1989.34.4.0673.

SMITH, M.E., 1986. Distribution patters and sazonal occurence of Rhabdostyla sp. (Peritrichia: Epistylididae) on Dero nivea (Oligochaeta: Naididae). American Midland Naturalist, vol. 116, no. 2, pp. 348-355. http://dx.doi.org/10.2307/2425743.

TAKEDA, A.M., 1999. Oligochaeta community of alluvial upper Paraná River, Brazil: spatial and temporal distribution 
(1987-1988). Hydrobiologia, vol. 412, pp. 35-42. http://dx.doi. org/10.1023/A:1003844131148.

WAHL, M., 1989. Marine epibiosis. 1. Fouling and antifouling: some basic aspects. Marine Ecology Progress Series, vol. 58, pp. 175-189. http://dx.doi.org/10.3354/meps058175.
ZINGEL, P., AGASILD, H., NOGES, T. and KISAND, V., 2007. Ciliates are the dominant grazers on pico and nanoplankton in a shallow, naturally highly eutrophic lake. Microbial Ecology, vol. 53, no. 1, pp. 134-142. http://dx.doi.org/10.1007/s00248-006-9155-4. PMid:17186145. 